\title{
RAB44 Gene
}

National Cancer Institute

\section{Source}

National Cancer Institute. RAB44 Gene. NCI Thesaurus. Code C162426.

This gene is involved in GT P-mediated signaling and neutrophil degranulation. 